\title{
The effect of nitrogen on the root and shoot development of Lolium multiflorum var. westerwoldicum
}

\author{
J. J. Schuurman and L. Knot \\ Institute for Soil Fertility, Haren (Gr.), the Netherlands
}

Accepted: 9 November 1973

\section{Summary}

The influence of nitrogen on the growth of shoots and roots of Lolium multiflorum has been studied. For this purpose this grass species was planted on artificial soil profiles with three nitrogen supplies and a soil water level at a depth of $70 \mathrm{~cm}$. Samplings were carried out on two data.

It was found that the top growth responded considerably to the nitrogen supplies with simultaneous differences in water consumption and assumedly also nitrogen uptake. Root weights reacted in a similar way. Increased supply of nitrogen resulted - as might be expected - in enhanced shoot-root ratios, especially on 14 July. It may be accepted that increased morphological development of the root system has contributed considerably to the better top growth. The numbers of main and secondary roots must have been the most important characteristics of the root systems in this respect.

The increase in root weights and root surface could not account for the complete increase of top growth. Root activity must also have increased according to the nitrogen supplies.

\section{Introduction}

Root development of grasses as influenced by nitrogen has been investigated by many authors with many species. Reid (1933) found with Agrostis a decrease of roots with increasing amounts of nitrogen. Sprague (1934) had the same result with Agrostis in an experiment in the spring, but the reverse in one during winter. According to Watkins (1940) a fertilization of Bromus inermis in a young stage with sulphate of ammonia promoted root growth. In a later stage, however, root growth was hampered. Pink \& Allison (1947) saw no influence of ureum on the root development of Sudan grass at an age of 25 days. Amounts of ureum up to $120 \mathrm{~kg} \mathrm{~N} /$ ha caused an increased root growth after 46 and 75 days. The root weights remained more or less constant with amounts higher than $120 \mathrm{~kg} / \mathrm{ha}$. Goedewaagen (1952) with pasture, stated a decrease of root growth with increasing amounts of nitrogen. Troughton (1956) found that a combined supply of nitrate and ammonia caused an increase in the root development of young plants of Phleum pratense. Haas (1958) reports an increase in root growth in the top layer of $30 \mathrm{~cm}$ as well as in the subsoil with Agropyron desertorum, Elymus junceus and Bromus inermis by $\mathrm{N}$ fertilization. Lippert (1959), working with monocultures of Poa pratensis, Festuca rubra and Dactylis glomerata, found an in- 
crease of roots in three-year old plants with increasing amounts of nitrogen. Oswalt et al. (1959) saw with Bromus and Dactylis that the root weights with a fertilization of $300 \mathrm{~N}$ were inferior to those of $0 \mathrm{~N}$ when the interval between two clippings was short and exceeded those of $0 \mathrm{~N}$, when these were longer. Mitchell (1961) studied the root growth of Dactylis glomerata at supplies of 0 and 150 pounds of nitrogen per acre ( $\sim 168 \mathrm{~kg} / \mathrm{ha}$ ). Fertilization with $\mathrm{N}$ in general resulted in a decrease of root weights. Slaats \& Behaeghe (1965) stated an increase of root weights of Lolium perenne with supplies of nitrogen up to $300 \mathrm{~N}$, followed by a decrease with higher amounts. These changes in root weight were mainly found in the top $5 \mathrm{~cm}$ of the soil. The maximum in this layer was attained with $300 \mathrm{~N}$, in the layer of $5-60 \mathrm{~cm}$ with $100 \mathrm{~N}$. Richardson (1953) measured the length growth of the roots of Lolium perenne. He found that the length increased when the nitrogen amounts decreased. This result was confirmed by Oswalt et al. (1959) with Bromus and Dactylis and by Brouwer et al. (1961) with Lolium perenne.

It is shown in this survey that the results of the various species concerning the root mass are conflicting, whereas those of the length growth are more unanimous. A striking point is moreover that data on details of roots are nearly completely missing. An experiment that has been carried out with three amounts of nitrogen gives data about the response of Lolium multiflorum. In this paper more detailed data are given about root weights and the significance of this factor for uptake.

\section{Materials and methods}

Plants were grown on artificial profiles of sandy soil in asbestos tubes with an inner diameter of $15 \mathrm{~cm}$ and a height of $75 \mathrm{~cm}$. The bulk density was in all cases $1.4 \mathrm{~g} / \mathrm{cm}^{3}$. The humus content was $5.3 \%$, the $\mathrm{pH}-\mathrm{KCl} 4.5$ and the $\mathrm{N}$ content $2.1 \mathrm{mg} / \mathrm{kg}$. Supplies of ammonium nitrate limestone were broadcast at rates of 25,50 or $100 \mathrm{~kg} \mathrm{~N} / \mathrm{ha}$. Phosphate and potassium were given in liberal amounts. The soil water level was maintained at a depth of $70 \mathrm{~cm}$ below soil level. The amounts of water that was replenished were recorded. On each profile three plants were grown. The experiment was carried out in triplicate.

Samplings were carried out in triplicate on 14 July and 17 August, that is 8 and 13 weeks after sowing, respectively. The roots of one of the three profiles of each treatment were selected for detail investigations.

The characteristics of the root system that may be influenced by nitrogen are: 1) total root weight; 2) depth of rooting; 3) distribution of the roots in the profile; 4) total number of main roots. Of the individual roots the characteristics are: 1) length and diameter; 2) formation of branch roots.

For the study of detail characteristics the roots of the three plants of the selected profile were separated without considerable damage of the individual roots and their branches. The roots of two out of these three plants were disentangled and clipped at the insertion. These roots were used for detail investigations. When there was a great conformity between the roots of these two plants those of the third plant were only counted and weighed. The roots of the plants of the remaining two profiles were also counted and weighed after drying.

The tops of the plants were clipped, dried and weighed.

The consumption of water was calculated from the amounts of water that were replenished during the experiment and the rainfall. 


\section{Results}

The data of the measurements are summarized in Table 1 and Fig. 1. Pictures of the root systems of 14 July and tops and root systems of 17 August are given in Fig. 2 .

It appears from Table 1 that the top growth has responded considerably on both dates to the higher amounts of nitrogen. Fig. 2 confirms this for the plants on 17 August. This has been accompanied by large differences in water consumption per plant. This means that the roots have taken up greater amounts of water with increasing nitrogen supplies. The increase in water consumption was, however, smaller than that of the weight of the shoots, so that the water use per $g$ dry matter diminished in the same sequence. Nitrogen uptake has not been determined but it may be assumed

Table 1. Results per plant (average values).

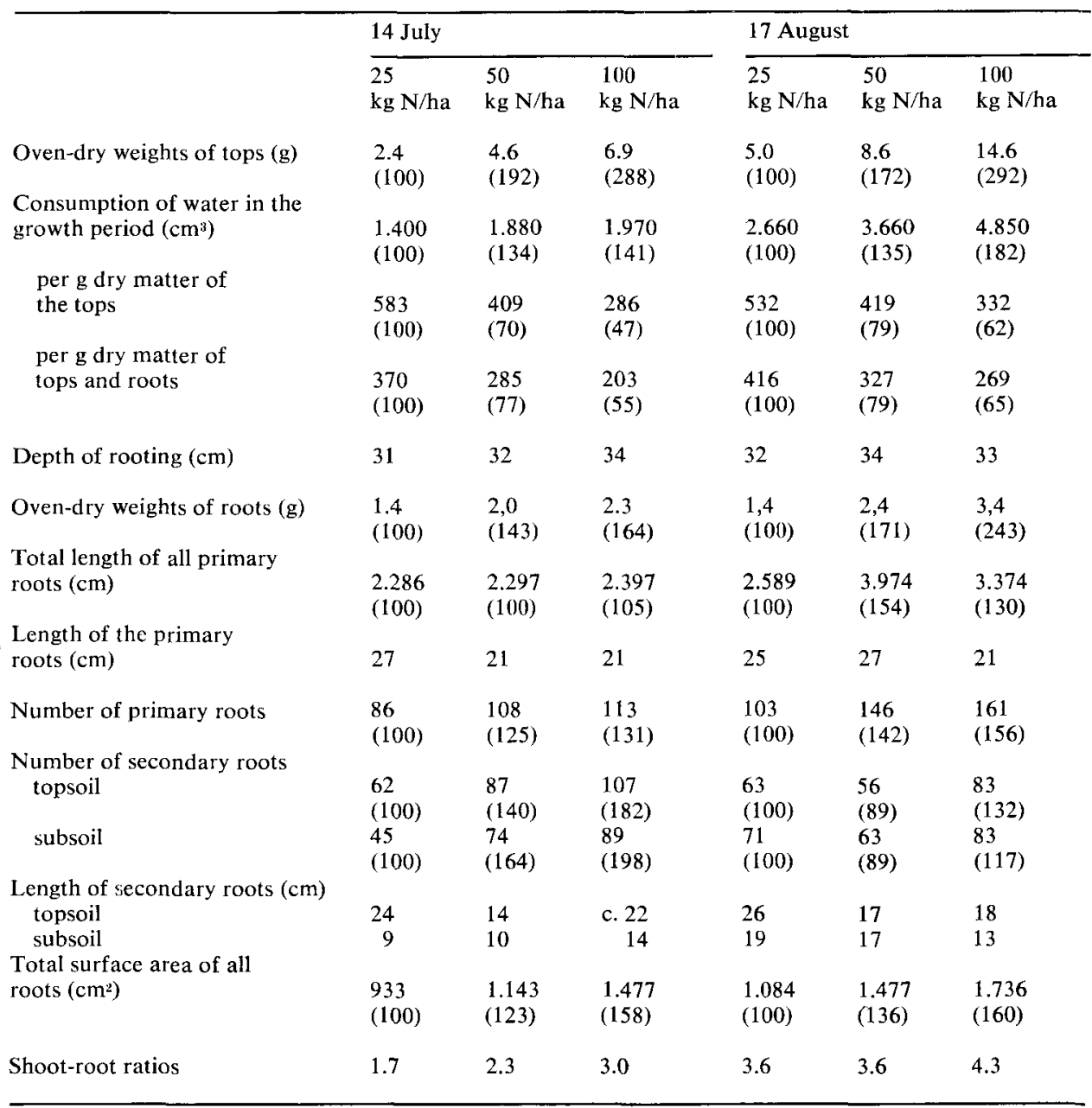


from other data (Schuurman, unpublished; Goedewaagen, 1942; Dilz, 1964) that the large differen:es in top growth were accompanied by differences in nitrogen uptake that were relatively of the same order of magnitude or larger. Having pointed to the differences between the shoots we may now turn to the roots. Table 1 shows that shoot weights responded much more to increasing nitrogen than root weights.

The question may now be put forward whether these latter differences coincided with either only disparities in morphological development of the root systems or with a higher activity of the roots or with both. By root activity we understand the amount of nutrient taken up by employment of energy by unit of root (either weight or surface area) in unit of time.

Table 1 shows that there were higher root weights on both data with increasing amounts of nitrogen. It is therefore without doubt that root weights can increase with progressive amounts of nitrogen. The only possible explanations for reduced root weights - as were found also by other authors - can be that these either were caused by adventitious conditions that were not recognized, or that authors worked with amounts of nitrogen fitting in the decreasing traject of a curve. The second explanation seems to be the most acceptable one, but then it must be assumed that the fundamental response of root growth to increasing amounts of nitrogen fits a curve with a distinct optimum. In this respect it may be also pointed out that various grass species have been used that may attain maximum root weights at different nitrogen amounts, which fact can also have contributed to the apparent contradictory results. Hitherto we have not had the opportunity to test this hypothesis but support is found in the results given by Troughton (1957) and by Slaats \& Behaeghe (1965), who found in fact an optimum curve.

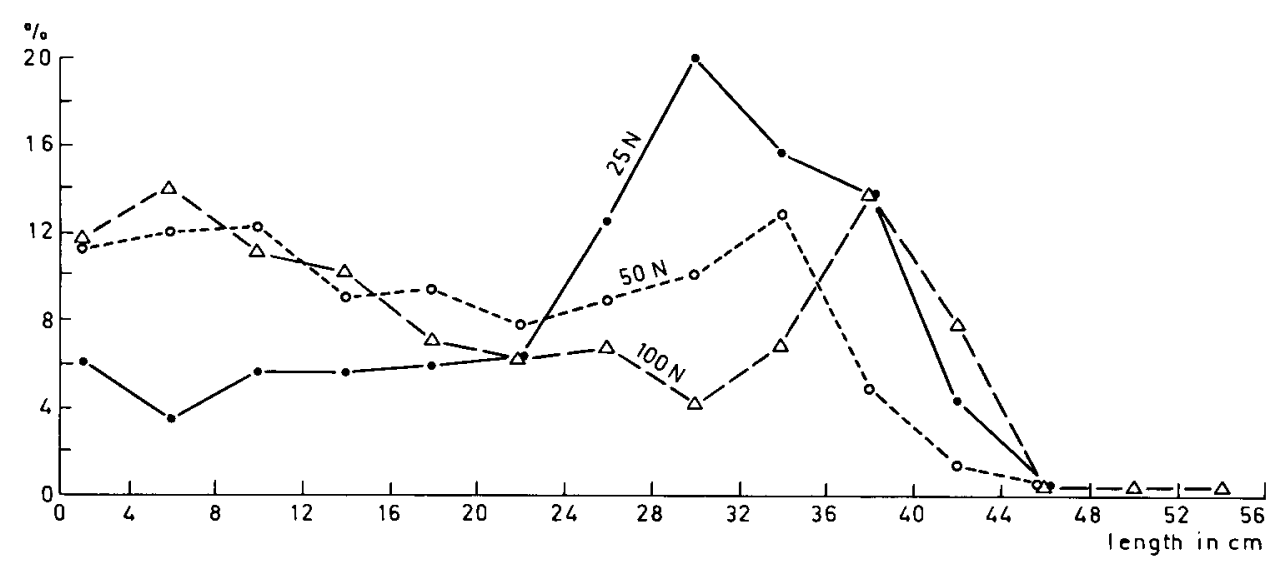

Fig. 1. Frequency distribution of the length of the roots on $14 \mathrm{July.}$

\begin{tabular}{llll}
\hline $\begin{array}{l}\text { N gift } \\
(\mathrm{kg} / \mathrm{ha})\end{array}$ & \multicolumn{3}{l}{ Length percentages } \\
\cline { 2 - 4 } & $<24 \mathrm{~cm}$ & $24-40 \mathrm{~cm}$ & $>40 \mathrm{~cm}$ \\
25 & 33.2 & 61.7 & 5.1 \\
50 & 61.6 & 36.4 & 2.0 \\
100 & 60.0 & 31.3 & 8.7 \\
\hline
\end{tabular}


A point of particular interest is that the relative figures demonstrate that these increases in root weight were inferior to those of the tops, especially in July. The consequence of this is that the shoot-root ratio increased progressively with increasing amounts of nitrogen. This result has been found by other authors. A consequence of the comparison of the relative figures is also that the relatively greater shoot growth can be attributed only partly to the increase of the root systems expressed by root weights. This means that one or more factors must have contributed too to the higher uptake. In principle these factors can be: 1) distribution of the roots in the soil; 2) type of root; 3) activity of the roots; 4) concentration of the soil solution. Either of these factors would be able to influence the uptake.

The distribution of the roots in the soil can be deduced from the length frequency data of the roots. The data of July are given in Fig. 1. It is evident from this figure that a maximum was found with roots 24 to $40 \mathrm{~cm}$ long in all treatments. The length with the highest frequency decreased with increasing amounts of nitrogen. There was in the treatments with 50 and $100 \mathrm{~N}$ another top of very short roots that was absent with $25 \mathrm{~N}$. Nevertheless the main roots were those with the greater length and the differences between these were not such that root distribution has been an important factor causing disparities in uptake to a considerable extent.

Root diameter may be seen as an important characteristic for root type. We calculated the average root diameter in the various treatments from the total root weights and root lengths. Data in literature of root diameter as it is affected by nitrogen are rather scarce and contradictory (Reid, 1933; Mulder, 1954). Gliemeroth (1955), in a publication giving various details, does not mention differences.

For this calculation it was necessary to make two assumptions, i.e. that dry matter percentages in the roots of all treatments were roughly 8 and specific weights of fresh roots were 1. It was found that this average root diameter tended to increase with increasing amounts of nitrogen. From these data and the total length of all roots that were measured it was possible to make an approximative calculation of the root surface areas (Table 1). These data allow for the conclusion that the root surface area increased on both data progressively with increasing amounts of nitrogen. The relative data show that these increases in root surface area can also account partially for the enhanced shoot growth in the treatments with the higher nitrogen supply.

In the foregoing two factors have been forwarded that were held to be partially responsible for the enhanced uptake in the treatments with higher amounts of nitrogen. Both factors together can account at a maximum for the major part of the increase in uptake but not completely. It has therefore to be assumed that root activity has increased too.

A conclusion that can be drawn also from the data of Table 1 about root growth is that root weights in the treatment with $25 \mathrm{~N}$ have not increased after 14 July, those with $50 \mathrm{~N}$ increased by approximately $20 \%$ and those with $100 \mathrm{~N}$ by about $50 \%$. This suggests that the period of root growth in this experiment was extended by higher nitrogen fertilization.

Having stressed the importance of root weights with regard to plant growth, it will be of interest to see which particulars of the root system have affected the root weights.

Fig. 2. Lolium multiflorum var. westerwoldicum Top: root systems, 14 July.

Bottom: shoots and roots, 17 August. 
EFFECT OF NITROGEN ON ROOTS AND SHOOTS OF LOLIUM MULTIFLORUM
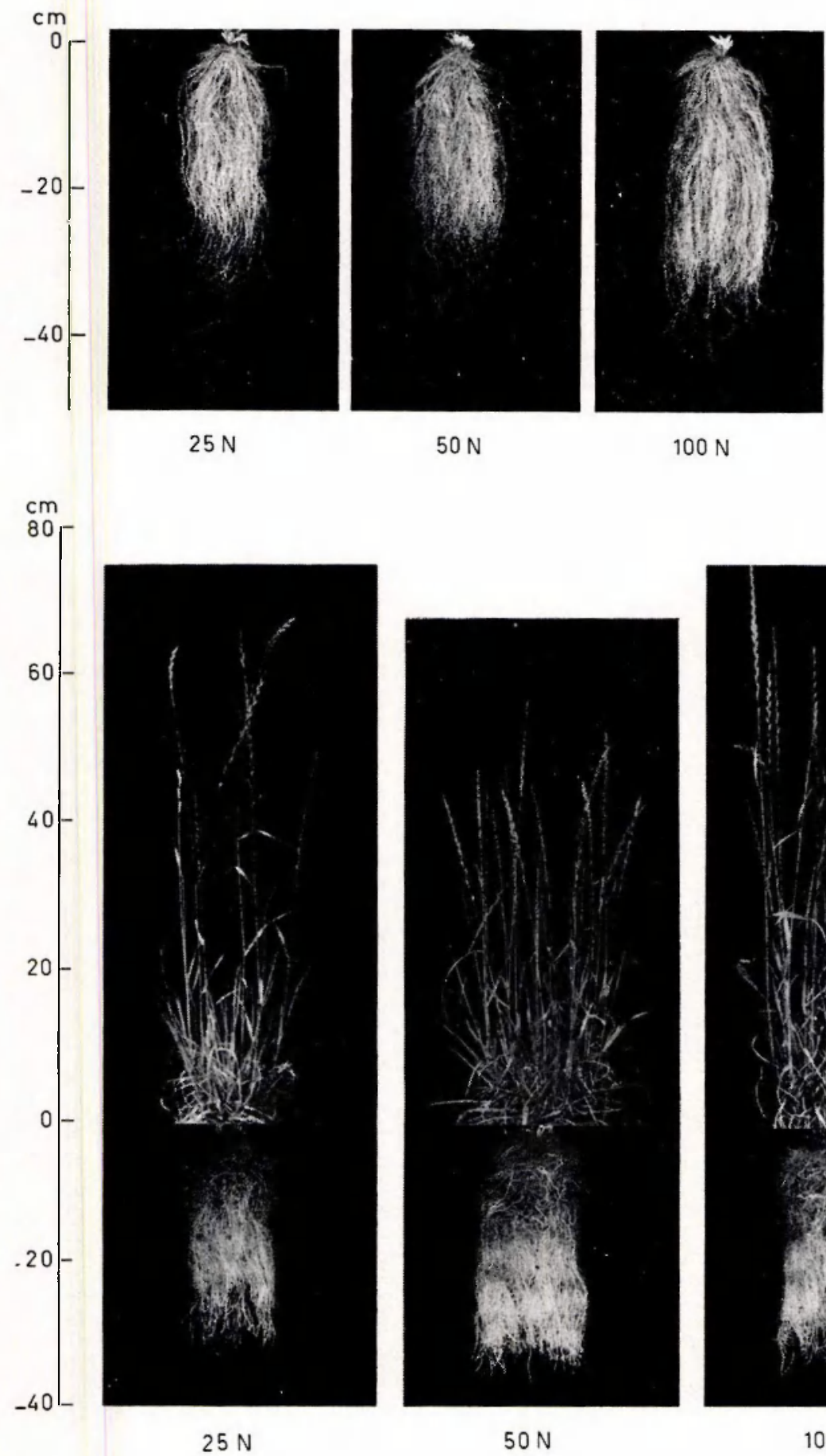

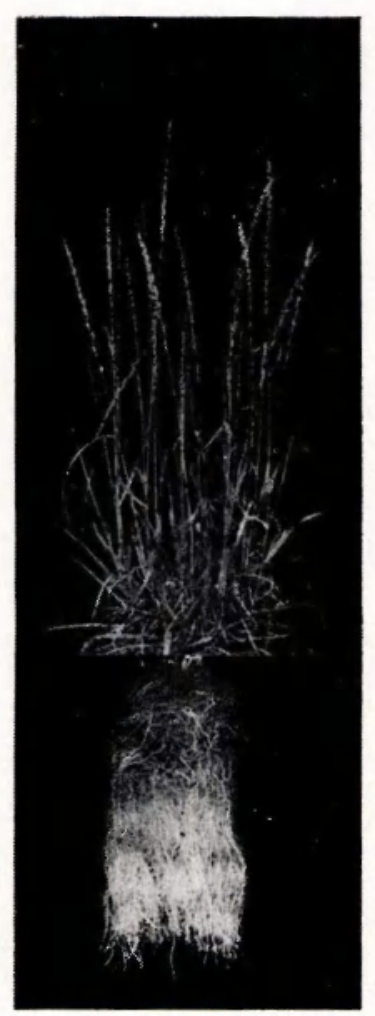

$50 \mathrm{~N}$

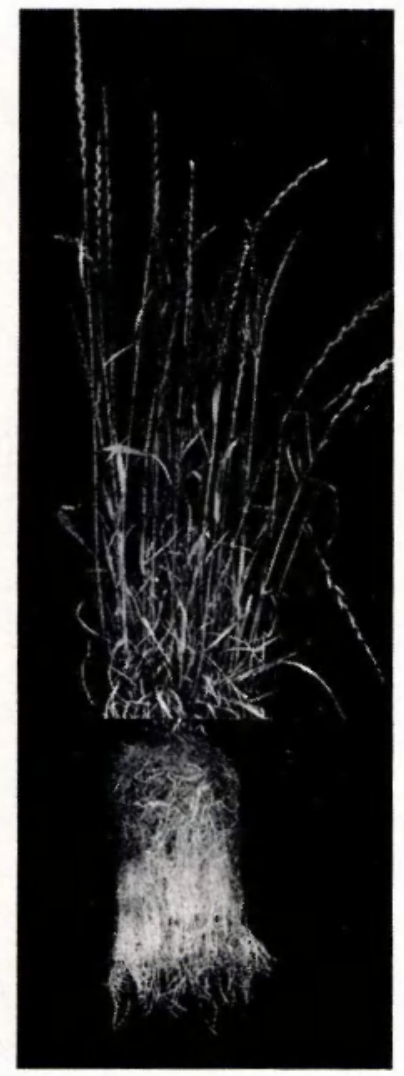

$100 \mathrm{~N}$

Neth. J. agric. Sci. 22 (1974) 
In principle these can have been the following characteristics: 1) numbers of main roots; 2) length of main roots; 3) numbers of secondary roots; 4) length of secondary roots; 5) diameter of roots.

It is found from Table 1 that the numbers of main roots increased considerably in consequence of higher amounts of nitrogen, although relatively to a smaller degree than the root weights. This implies that there have been one or more other factors that contributed too in the higher root weights. This has not been the length of the main roots, because the total length of all main roots increased to a lesser degree than the numbers, so that there was rather a tendency to a decrease in average root length. However, the numbers of secondary roots in the topsoil as well as in the subsoil increased in July, according to nitrogen supply. Therefore this may be seen as a cause of increased root weights. Finally, the average root diameter tended also to increase progressively with nitrogen fertilization. The length of the secondary roots did not vary consistently and consequently did not contribute to the differences in root weight.

\section{References}

Brouwer, R., P. J. Jenneskens \& G. J. Borggreve, 1961. Growth responses of shoots and roots to interruptions of the nitrogen supply. Jaarb. Inst. biol, scheik. Onderz. LandbGewass. 1961: 29-36.

Dilz, K., 1964. Over de optimale stikstofvoeding van granen. Thesis, Landbouwhogeschool Wageningen.

Gliemeroth, G., 1955. Wirkung der Düngerverteilung auf die Wurzelausbildung. In: De plantenwortel in de landbouw. Ministerie van Landbouw, Visserij en Voedselvoorziening, 's-Gravenhage.

Goedewaagen, M. A. J., 1952. Wortelontwikkeling en droogteschade in het gewas, in het bijzonder op grasland. Comm. hydrol. Onderz. T.N.O., Versl. tech. Bijeenkomsten 1-6: 206-222.

Haas, H. J., 1958. Effects of fertilizers, age of stand and decomposition on weight of grass roots and of grass and alfalfa on soil nitrogen and carbon. Agron. J. 50: 5-9.

Lippert, G., 1959. Beitrag zur Wurzelentwicklung der Gräser in Reinbeständen unter Einwirkung der Beregnung und der Stickstoffdüngung. Kulturtechniker 47: 251-262.

Mitchell, W. H., 1961. A study of the root and top growth of several forage species as influenced by nitrogen and irrigation treatments. Dissertation, Pennsylvania State University.

Mulder, E. G., 1954. Effect of mineral nutrition on lodging of cereals. Pl. Soil 5: 246-306.

Oswalt, D. L., A. R. Bertrand \& M. R. Teel, 1959. Influence of nitrogen fertilization and clipping on grass roots. Proc. Soil Sci. Soc. Am. 23: 228-230.

Pinck, L. A. \& F. E. Allison, 1947. The effect of rate of nitrogen applications upon the weight and nitrogen content of the roots of Sudan grass. Agron. J. 39: 634-637.

Reid, M. E., 1933. Effect of variations in concentration of mineral nutrients upon the growth of several types of turf grasses. Bull. U.S. Golf Ass. Green Sect. 13: 122-131.

Richardson, S. D., 1953. Root growth of Acer pseudoplatanus $L$. in relation to grass cover and nitrogen deficiency. Meded. LandbHogesch. Wageningen 53: 75-97.

Slaats, M. \& T. Behaeghe, 1965. Beknopt verslag over de periode 1963-1964. Nationaal Centrum voor Grasland- en Groenvoederonderzoek, 2e Sektie, Gent.

Sprague, H. B., 1934. Utilisation of nutrients by colonial bend (Agrostis tenuis) and Kentucky bluegrass (Poa pratensis). Bull. New Jers. agric. Exp. Stn 570: 16 pp.

Troughton, A. 1956. Studies of the growth of young grass plants with special reference to the relationship between the shoot and root systems. J. Br. Grassld Soc. 11: 56-65.

Troughton, A., 1957. The underground organs of herbage grasses. Bull. Commonw. Bur. Pastures Fld Crops 44: $163 \mathrm{pp}$.

Watkins, J. M., 1940. The growth habits and chemical composition of bromegrass, Bromus inermis Leyss, as affected by different environmental conditions. J. Am. Soc. Agron. 32: 527-538. 